University of Wollongong

Research Online

Faculty of Engineering and Information

Faculty of Engineering and Information

Sciences - Papers: Part A

Sciences

$1-1-2011$

Bauschinger effect in microalloyed steels: part II. Influence of work softening on strength development during UOE line-pipe forming

Andrii Kostryzhev

University of Birmingham, andrii@uow.edu.au

Martin Strangwood

University of Birmingham

Claire L. Davis

University of Birmingham

Follow this and additional works at: https://ro.uow.edu.au/eispapers

Part of the Engineering Commons, and the Science and Technology Studies Commons

Research Online is the open access institutional repository for the University of Wollongong. For further information contact the UOW Library: research-pubs@uow.edu.au 


\title{
Bauschinger effect in microalloyed steels: part II. Influence of work softening on strength development during UOE line-pipe forming
}

\author{
Abstract \\ The Bauschinger effect (a reduced yield stress at the start of reverse deformation following forward \\ prestrain) is an important factor of strength development for cold metal forming technology. In steels, the \\ magnitude of the Bauschinger effect depends on composition, through the presence of microalloy \\ precipitates, and prior processing, through the size and distribution of the microalloy precipitates and the \\ presence of retained work hardening. In this article, the parameters of the Bauschinger effect and work \\ hardening (coefficient and exponent) in forward and reverse deformations were quantitatively related to \\ the particle number density and dislocation density for two high-strength low-alloy (HSLA) steels. An \\ example of the application of the obtained dependences is discussed with respect to the strength \\ development during UOE forming of large diameter line pipes.
}

\section{Keywords}

steels, microalloyed, effect, bauschinger, uoe, during, pipe, development, strength, softening, work, influence, forming, ii, line, part

\section{Disciplines \\ Engineering | Science and Technology Studies}

\section{Publication Details}

Kostryzhev, A. G., Strangwood, M. \& Davis, C. L. (2011). Bauschinger effect in microalloyed steels: part II. Influence of work softening on strength development during UOE line-pipe forming. Metallurgical and Materials Transactions A: Physical Metallurgy and Materials Science, 42 (10), 3170-3177. 


\title{
Bauschinger Effect in Microalloyed Steels: Part II. Influence of Work Softening on Strength Development During UOE Line-Pipe Forming
}

\begin{abstract}
ANDRII G. KOSTRYZHEV, MARTIN STRANGWOOD, and CLAIRE L. DAVIS
The Bauschinger effect (a reduced yield stress at the start of reverse deformation following forward prestrain) is an important factor of strength development for cold metal forming technology. In steels, the magnitude of the Bauschinger effect depends on composition, through the presence of microalloy precipitates, and prior processing, through the size and distribution of the microalloy precipitates and the presence of retained work hardening. In this article, the parameters of the Bauschinger effect and work hardening (coefficient and exponent) in forward and reverse deformations were quantitatively related to the particle number density and dislocation density for two high-strength low-alloy (HSLA) steels. An example of the application of the obtained dependences is discussed with respect to the strength development during UOE forming of large diameter line pipes.
\end{abstract}

DOI: $10.1007 / \mathrm{s} 11661-011-0732-\mathrm{x}$

(C) The Minerals, Metals \& Materials Society and ASM International 2011

\section{INTRODUCTION}

THE high-strength low-alloy (HSLA) steel large diameter pipe body's mechanical properties are developed in two ways. The first is microstructure formation during plate rolling and its influence on the properties via grain refinement, solid solution and precipitation strengthening mechanisms, and work hardening. The second is the cold deformation schedule during pipe forming, which may result in a strength increase due to unidirectional loading (work hardening) or decrease due to reverse loading (the Bauschinger effect). The UOE forming process, used for production of large $(>400 \mathrm{~mm})$ diameter line pipes, includes several deformation stages: bending of a plate to U-shape, O-ing to form a circular cross section, and "killing" to close the plate edges before welding and expansion (E-stage) to form a final diameter after welding. The main feature of the UOE forming process, affecting the property distribution in the pipe cross section, is inequality of strain magnitude and deformation direction sequence for different areas of the plate cross section (Figure 1). The pipe segment opposite to the weld undergoes two full cycles of forward-reverse deformation and the plate edges (pipe segments close to the weld) one cycle of unidirectional and one of forward-reverse deformation. This may result in work softening from plate to pipe,

ANDRII G. KOSTRYZHEV, Research Fellow, is with the School of Electronic, Electrical and Computer Engineering, University of Birmingham, Edgbaston, Birmingham B15 2TT, United Kingdom. Contact e-mail: kostryzhev@yahoo.com MARTIN STRANGWOOD, Senior Lecturer, and CLAIRE L. DAVIS, Professor, are with the School of Metallurgy and Materials, University of Birmingham.

Manuscript submitted December 28, 2009.

Article published online May 25, 2011 especially in the segment opposite to the weld. ${ }^{[1,2]}$ The amount of possible strength loss depends on the pipe geometry, microstructure, and initial mechanical properties of the plate material. If the pipe body mechanical properties are measured using test coupons cut from flattened segments, usually taken from the $180 \mathrm{deg}$ position (opposite to the weld), additional deformation during flattening will occur and may result in the measured property value deviating from the real pipe value. This should be considered when assessing the pipe properties determined using the flattened specimen method.

Recent studies of plate to pipe property changes showed a different response of longitudinal and transverse strength to the deformation applied (Table I). In the pipe longitudinal direction, the yield stress increases from plate to pipe due to work-hardening $\left(\mathrm{YS}_{\text {pipe }}-\mathrm{YS}_{p l}\right.$, Table I). Flattening of samples prior to testing modifies this relation by an amount that depends on the steel grade $\left(\mathrm{YS}_{f p}-\mathrm{YS}_{p l}\right.$, Table I). In the transverse orientation, a decrease in the yield stress from plate to pipe was observed for microalloyed steels $\left(\mathrm{YS}_{f p}-\mathrm{YS}_{p l}\right.$, Table I). This can be explained by work softening during pipe forming and sample flattening prior to testing. To predict the final pipe strength, the yield stress change for each stage of the UOE forming process is needed. Strength development will depend on the plate microstructure (dislocation density and precipitate distributions) and cold deformation sequence (strain magnitude and direction).

In the present article, work hardening in the direction of forward and reverse deformation was studied for the $\mathrm{C}-\mathrm{Nb}$ and $\mathrm{C}-\mathrm{Nb}-\mathrm{V}$ steels (Table I). Using results from microstructural investigations, ${ }^{[4]}$ the plate to pipe property change was calculated for forming a $914 \times 25 \mathrm{~mm}$ pipe from the $\mathrm{C}-\mathrm{Nb}$ and $\mathrm{C}-\mathrm{Nb}-\mathrm{V}$ steels. 


\section{MATERIALS AND EXPERIMENTAL TECHNIQUES}

Mechanical properties were studied for the $\mathrm{C}-\mathrm{Nb}$ and $\mathrm{C}-\mathrm{Nb}-\mathrm{V}$ steels (Table I) in the as-rolled and annealed conditions. Annealing at $673 \mathrm{~K}$ and $823 \mathrm{~K}\left(400{ }^{\circ} \mathrm{C}\right.$ and $550{ }^{\circ} \mathrm{C}$ ) for 30 minutes was applied to modify the dislocation structure and microalloying element particle distributions, without affecting the grain size and secondphase content. Measurements (experimental technique and results) of dislocation density, using transmission electron microscopy (TEM) imaging, and $(\mathrm{Cu}+\mathrm{Ti}$, $\mathrm{Nb}, \mathrm{V})$-rich particle number density, using scanning and TEM imaging, are described in Reference 4.

Compression-tension testing was carried out on an ESH $250 \mathrm{kN}$ servohydraulic twin column low speed ramp universal testing machine. For the forward-reverse stress-strain curve determination, four standard round tensile test specimens of $4.5-\mathrm{mm}$ diameter and $13-\mathrm{mm}$ gage length were cut in an orientation transverse to the rolling direction from the $\mathrm{C}-\mathrm{Nb}$ and $\mathrm{C}-\mathrm{Nb}-\mathrm{V}$ as-rolled

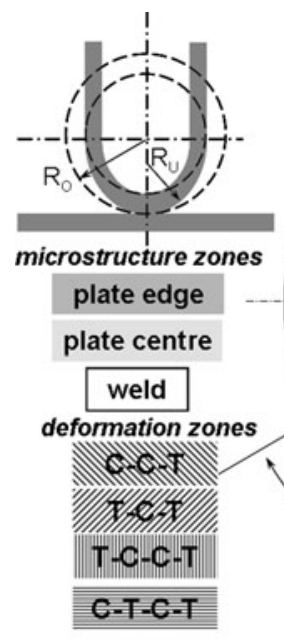

(a)

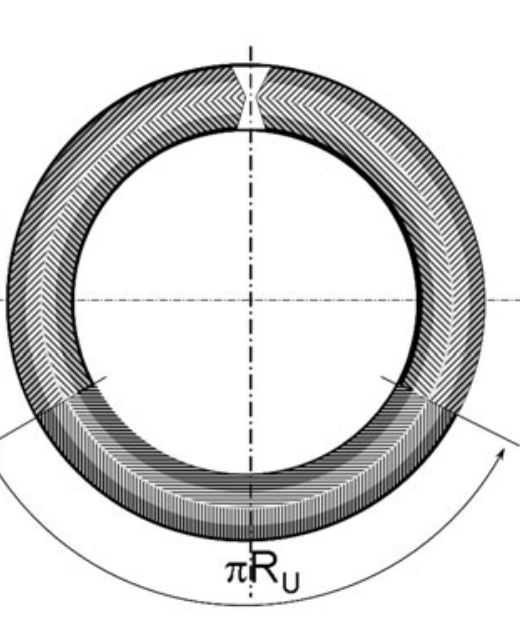

(b)
Fig. 1-(a) Schematic diagram of the pipe cross section after U-ing and O-ing: $\mathrm{R}_{\mathrm{U}}$ and $\mathrm{R}_{\mathrm{O}}$ - outer radii of a pipe after $\mathrm{U}$-ing and $\mathrm{O}$-ing. (b) Property zones in the pipe cross section after UOE forming: $C$-compression and $T$-tension. and annealed steel plates. The Bauschinger tests were carried out at room temperature by compressing the tensile test specimen to plastic strains of 0.3 to $4.9 \mathrm{pct}$ forward deformation, and then tensile testing until failure (reverse deformation) at a strain rate of $1.3 \times 10^{-4} \mathrm{~s}^{-1}$. Strain was measured using strain gages of KFG-2-120-C1 type permanently glued to the specimens in the middle of the reduced diameter section.

\section{RESULTS}

\section{A. Stress-Strain Dependence in Forward Direction}

The stress-strain curves from the as-rolled steels show two stages of work hardening: with a lower workhardening rate, up to 3 pct strain; and with an increased work-hardening rate, above 3 pct strain (Figure 2). This was observed previously in steels ${ }^{[5]}$ and is consistent with the long-range work-hardening theory: during the first stage of work hardening, slip occurs on the most favorable crystal planes, while during the second stage, slip occurs on all the possible slip planes, as the most favorable slip planes become blocked by pileups.

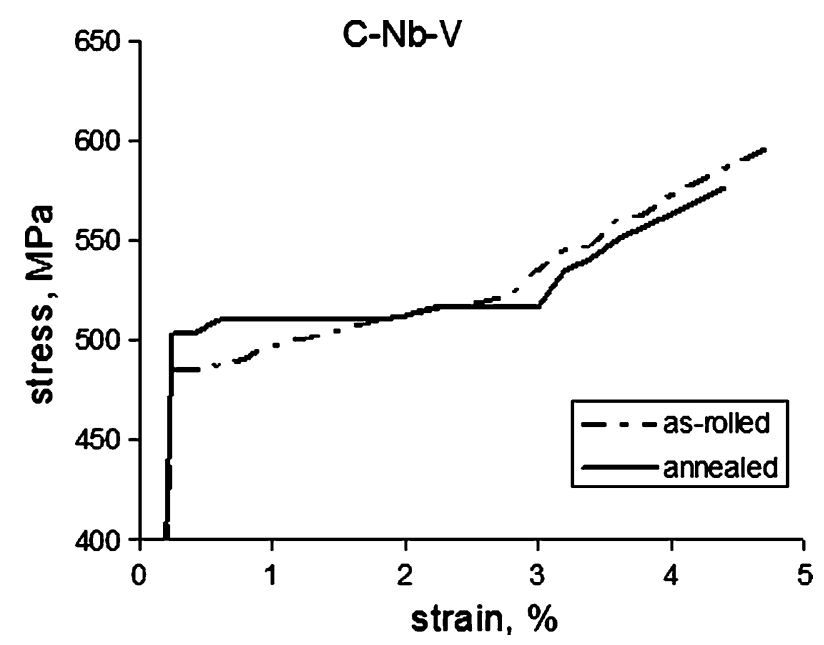

Fig. 2-Plastic part of stress-strain curves during forward deformation (compression) for the $\mathrm{C}-\mathrm{Nb}-\mathrm{V}$ steel in as-rolled and annealed $823 \mathrm{~K}\left(550{ }^{\circ} \mathrm{C}\right.$ for $\left.30 \mathrm{~min}\right)$ initial conditions.

Table I. Plate to Pipe Yield Stress Change, MPa (Derived from Ref 3)

\begin{tabular}{|c|c|c|c|}
\hline Steel grade & X52 (C-Mn) & $\mathrm{X} 60(\mathrm{C}-\mathrm{Nb})$ & X65 (C-Nb-V) \\
\hline Steel chemistry, wt pct & $0.12 \mathrm{C}-1.09 \mathrm{Mn}$ & $\begin{array}{l}0.10 \mathrm{C}-1.36 \mathrm{Mn}- \\
0.009 \mathrm{Cu}-0.034 \mathrm{Nb}\end{array}$ & $\begin{array}{l}0.07 \mathrm{C}-1.47 \mathrm{Mn}-0.015 \mathrm{Cu}- \\
0.046 \mathrm{Nb}-0.061 \mathrm{~V}\end{array}$ \\
\hline \multicolumn{4}{|l|}{ Orientation } \\
\hline \multicolumn{4}{|l|}{ Longitudinal } \\
\hline Plate, $\mathrm{YS}_{p l}$ & 357 & 458 & 498 \\
\hline Pipe, $\mathrm{YS}_{\text {pipe }}$ & 378 & 473 & 514 \\
\hline Flattened pipe, $\mathrm{YS}_{f p}$ & 397 & 447 & 523 \\
\hline $\mathrm{YS}_{\text {pipe }}-\mathrm{YS}_{p l}$ & +21 & +15 & +16 \\
\hline $\mathbf{Y S}_{f p}-\mathrm{YS}_{p l}$ & +40 & -11 & +25 \\
\hline \multicolumn{4}{|l|}{ Transverse } \\
\hline Plate, $\mathrm{YS}_{p l}$ & 352 & 481 & 528 \\
\hline Flattened pipe, $\mathrm{YS}_{f p}$ & 390 & 478 & 519 \\
\hline $\mathrm{YS}_{f p}-\mathrm{YS}_{p l}$ & +38 & -3 & -9 \\
\hline
\end{tabular}




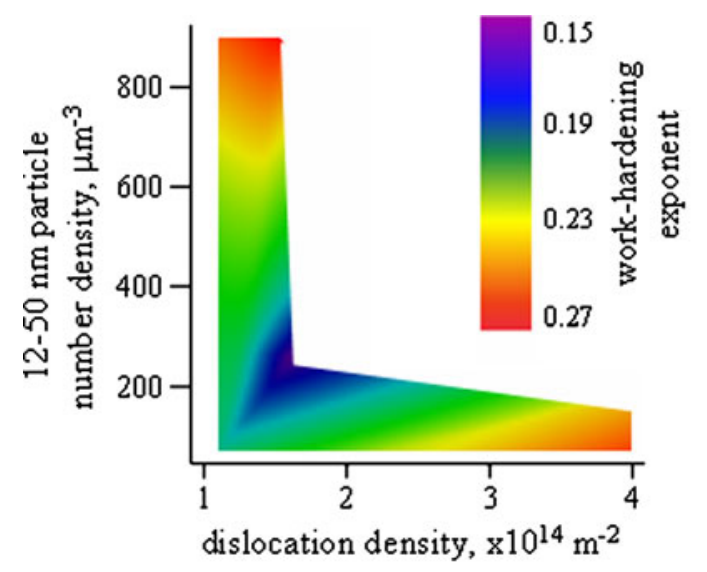

(a)

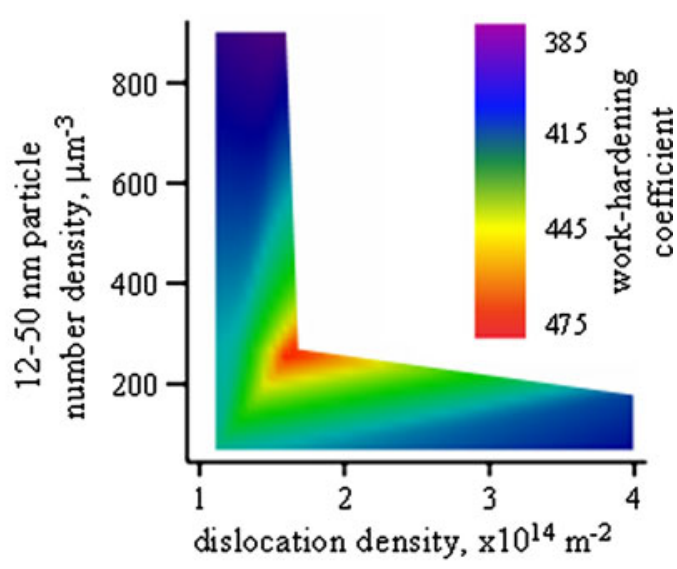

(b)

Fig. 3- (a) Work-hardening exponent and $(b)$ work-hardening coefficient dependence on dislocation density and $(\mathrm{Cu}+\mathrm{Ti}, \mathrm{Nb}, \mathrm{V})$-rich particle number density for above 3 pct forward strain (compression).

In contrast, the stress-strain curves of the initially annealed steels show a Lüders strain region; a part of the stress-strain curve parallel to the strain axis where yielding occurs without stress increase (Figure 2). This can be explained by easy glide of free dislocations left after annealing, followed by the generation of new mobile dislocations.

Within the separate work-hardening regions, the stress-strain experimental curves were approximated by a power equation $\sigma=K \varepsilon^{n}$ (where $\sigma=$ stress, $\varepsilon=$ strain, $K=$ work-hardening coefficient, and $n=$ workhardening exponent) and related to the microstructural parameters for the same material conditions. ${ }^{[4]}$ Analysis of the work-hardening behavior dependence on the microstructural parameters showed that, with an increase in dislocation density and microalloying element $((\mathrm{Cu}+$ $\mathrm{Ti}, \mathrm{Nb}, \mathrm{V}$ )-rich) particle number density (determined from scanning electron microscopy and TEM measurements $\left.{ }^{[4]}\right)$, the work-hardening exponent increases (Figure 3(a)) and the work-hardening coefficient (for $\varepsilon \leq 3 \mathrm{pct}$ ) decreases (Figure 3(b)). Dislocation density was determined from line length measurements from TEM images taken under multiple two beam conditions. ${ }^{[4]}$ The influence of dislocation density on the parameters of work hardening was observed to be higher than that of the particle number density within the range of values examined.

\section{B. Stress-Strain Dependence in Reverse Direction}

The reverse stress-strain curves show lower stress values than the corresponding forward stress-strain curve due to work softening (Figures 4). If unloading after forward prestrain occurs from the region of low work-hardening rate, i.e., below 2.8 pct plastic prestrain in the studied steels, a region of easy flow (a plateau) at a constant or decreasing stress is present on the reverse stress-strain curve. This type of behavior was observed before in $\mathrm{fcc}^{[6]}$ and $\mathrm{bcc}^{[7]}$ materials. In the present work, the plateau length can be related to the dislocationparticle interaction process: with an increase in the number of potential dislocation-particle interaction sites, the plateau length decreases. It can be supported by the observed plateau length (Figure 4):

(1) decreasing with an increase in prestrain, leading to an increase in dislocation density (compare the traces for $\mathrm{C}-\mathrm{Nb}-\mathrm{V}$ as rolled after 0.3 and $2.8 \mathrm{pct}$ prestrain and for $\mathrm{C}-\mathrm{Nb}-\mathrm{V}$ annealed at $673 \mathrm{~K}$ $\left(400^{\circ} \mathrm{C}\right)$ after 0.5 and 2.1 pct prestrain);

(2) increasing after low-temperature annealing, leading to a decrease in dislocation density (compare the traces for $\mathrm{C}-\mathrm{Nb}-\mathrm{V}$ as rolled after 0.3 pct prestrain and for $\mathrm{C}-\mathrm{Nb}-\mathrm{V}$ annealed at $673 \mathrm{~K}\left(400{ }^{\circ} \mathrm{C}\right)$ after $0.5 \mathrm{pct})$; and

(3) decreasing with an increase in annealing temperature, leading to an increase in particle number density due to precipitation of new particles (compare the traces for $\mathrm{C}-\mathrm{Nb}-\mathrm{V}$ annealed at $673 \mathrm{~K}\left(400{ }^{\circ} \mathrm{C}\right)$ after 2.1 pet prestrain and for $\mathrm{C}-\mathrm{Nb}-\mathrm{V}$ annealed at $823 \mathrm{~K}\left(550^{\circ} \mathrm{C}\right)$ after 1.9 pct prestrain).

Approximation of the reverse stress-strain curves, as seen in Figure 4, by the power equation $\sigma=K \varepsilon^{n}$ showed that the work-hardening exponent is independent, and the work-hardening coefficient is dependent, on prestrain (Table II). For the "below 0.7 pct" reverse strain range, the work-hardening coefficient increases with an increase in forward prestrain, after a minimum at 1 to 3 pct prestrain. This minimum can be explained by the generation of new dislocations, free from obstacles, during the first stages of forward prestraining, i.e., below 3 pct, which facilitates slip during reverse deformation. With an increase in forward prestrain, the dislocation density and the number of dislocationobstacle interaction sites increase significantly, which leads to the work-hardening coefficient in the reverse direction increasing. For the "above 0.7 pct" reverse strain range, the work-hardening coefficient steadily increases with an increase in forward prestrain, due to the total increase in dislocation density. For the same level of prestrain, the work-hardening coefficient was observed to be higher and the work-hardening exponent to be lower in the more highly alloyed steel, i.e., $\mathrm{C}-\mathrm{Nb}-\mathrm{V}$. In the $\mathrm{C}-\mathrm{Nb}$ steel, the work-hardening coefficient 


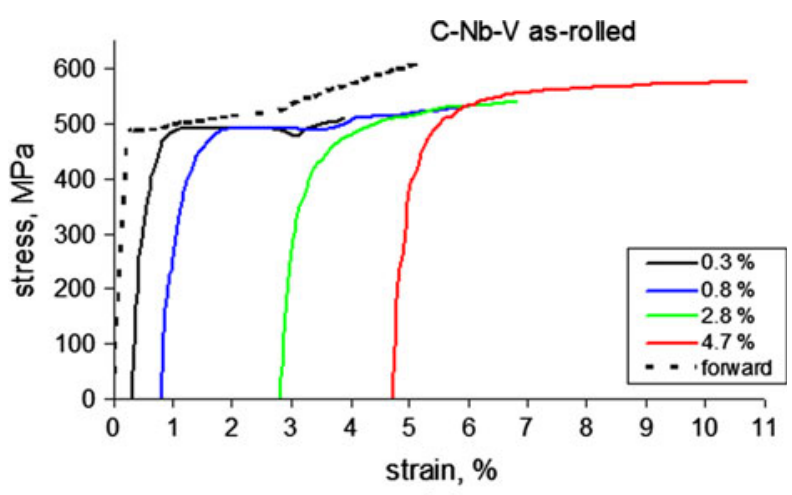

(a)

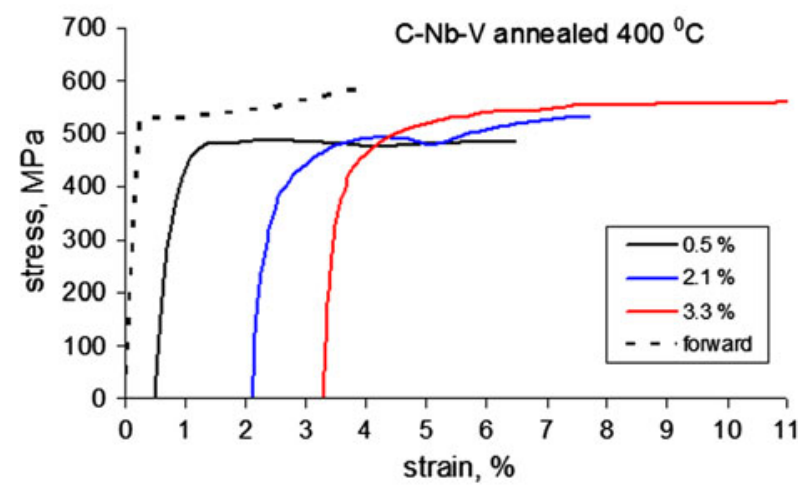

(b)

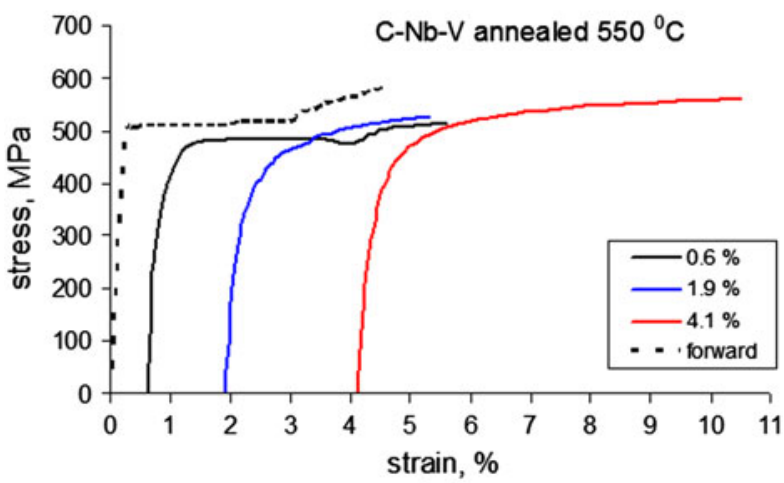

(c)

Fig. 4-Reverse (tension) stress-strain curves for the $\mathrm{C}-\mathrm{Nb}-\mathrm{V}$ steel in $(a)$ as-rolled and $(b)$ and $(c)$ annealed conditions for different levels of forward prestrain (compression is shown by dashed lines).

decreased and the work-hardening exponent did not show any change with annealing. However, in the $\mathrm{C}-\mathrm{Nb}-$ $\mathrm{V}$ steel, the work-hardening exponent and coefficient decreased after annealing at $673 \mathrm{~K} \quad\left(400{ }^{\circ} \mathrm{C}\right)$ and increased after annealing at $823 \mathrm{~K}\left(550^{\circ} \mathrm{C}\right)$.

Analysis of the work-hardening behavior dependence on the microstructural parameters showed that, with an increase in dislocation density and microalloying element particle number density, the work-hardening exponent decreases and the work-hardening coefficient increases (Figure 5). The relative influence of the dislocation density on the parameters of work hardening during reverse deformation was observed to be higher than the particle number density influence over the range of values examined. In summary, the effect of alloying and initial work hardening on the work-hardening behavior during reverse deformation should result in a lower work-hardened but higher alloyed steel more quickly returning to its forward direction properties.

\section{DISCUSSION}

An example discussed subsequently shows prediction of strength development during the UOE pipe forming process. The yield stress was calculated for the area opposite to the weld during forming of a 914-mm outside diameter $25-\mathrm{mm}$ wall thickness pipe from the $\mathrm{C}-\mathrm{Nb}$ and $\mathrm{C}-\mathrm{Nb}-\mathrm{V}$ steels (Table III). The stress-strain curve approximation equations were determined using the dependences of the work-hardening parameters on particle number density and dislocation density (Figures 3 and 5). Industrial measurements of technological parameters, described in Reference 3, were used to calculate the strain distribution in each stage of the UOE pipe forming process ${ }^{[8]}$ (Figure 6).

For each stage of the UOE forming process, the following assumptions were made (Sections IV-A through IV-E).

\section{A. U-ing}

Strains in the outside and inside surface layers of the pipe wall were calculated using equations for simple bending; i.e., shear deformation was neglected and the position of the neutral layer was assumed to be constant at the plate midthickness. Particle number density and dislocation density values for the inside and outside surface layers were taken to be those for the plate subsurface (Table III). The yield stress in the surface layers was calculated using equations for forward work hardening (Figure 3); deformation at the midthickness, and associated property changes, was neglected. Dislocation density change during U-ing was calculated using the following equation derived from the literature data (Figure 10 of Reference 9) of the dislocation density dependence on strain for unidirectional deformation:

$$
\Delta \rho=\varepsilon \times 0.15 \times 10^{14} \mathrm{~m}^{-2}
$$

where $\Delta \rho$ is the dislocation density increase and $\varepsilon$ is strain in percent.

\section{B. $O$-ing}

Strains in the surface layers were calculated using equations for simple bending. Particle number density was taken as for the plate subsurface (Table III). Dislocation density values took into account the increase after U-ing. The yield stress in the surface layers was calculated using equations for reverse work hardening (Figure 5); deformation at the midthickness, and any associated property changes, was neglected. Dislocation density change during O-ing was calculated using the following equation derived from the literature 
Table II. Approximate Equations for the Reverse Stress-Strain Curves

\begin{tabular}{|c|c|c|c|}
\hline \multirow[b]{2}{*}{ Steel Grade } & \multirow{2}{*}{$\begin{array}{c}\text { Forward } \\
\text { Prestrain, Pct }\end{array}$} & \multicolumn{2}{|c|}{ Reverse Stress-Strain Curve Approximation Equation } \\
\hline & & Below 0.7 Pct Strain & 0.7 to 5.0 Pct Strain \\
\hline \multirow[t]{4}{*}{$\mathrm{C}-\mathrm{Nb}$ as rolled } & 0.3 & $560 \cdot \varepsilon^{0.42}$ & $475 \mathrm{MPa}$ \\
\hline & 0.9 & $480 \cdot \varepsilon^{0.42}$ & $430 \cdot \varepsilon^{0.11}$ \\
\hline & 2.8 & $500 \cdot \varepsilon^{0.42}$ & $460 \cdot \varepsilon^{0.11}$ \\
\hline & 4.9 & $520 \cdot \varepsilon^{0.42}$ & $480 \cdot \varepsilon^{0.11}$ \\
\hline \multirow[t]{3}{*}{$\mathrm{C}-\mathrm{Nb}$ annealing $823 \mathrm{~K}\left(550^{\circ} \mathrm{C}\right)$} & 0.5 & $530 \cdot \varepsilon^{0.42}$ & $478 \mathrm{MPa}$ \\
\hline & 1.8 & $450 \cdot \varepsilon^{0.42}$ & $\begin{array}{l}\left(425 \cdot \varepsilon^{0.11} \text { above } 4 \mathrm{pct}\right) \\
440 \cdot \varepsilon^{0.11}\end{array}$ \\
\hline & 4.3 & $510 \cdot \varepsilon^{0.42}$ & $465 \cdot \varepsilon^{0.11}$ \\
\hline \multirow[t]{4}{*}{$\mathrm{C}-\mathrm{Nb}-\mathrm{V}$ as rolled } & 0.3 & $565 \cdot \varepsilon^{0.36}$ & $\begin{array}{l}487 \mathrm{MPa} \\
\left(445 \cdot 0^{0.09} \text { above } 3 \mathrm{pct}\right)\end{array}$ \\
\hline & 0.8 & $525 \cdot \varepsilon^{0.36}$ & $\begin{array}{l}497 \mathrm{MPa} \\
\left(455 \cdot \varepsilon^{0.09} \text { above } 3 \mathrm{pct}\right)\end{array}$ \\
\hline & 2.8 & $505 \cdot \varepsilon^{0.36}$ & $473 \cdot \varepsilon^{0.09}$ \\
\hline & 4.7 & $565 \cdot \varepsilon^{0.36}$ & $510 \cdot \varepsilon^{0.09}$ \\
\hline \multirow[t]{3}{*}{$\mathrm{C}-\mathrm{Nb}-\mathrm{V}$ annealing $673 \mathrm{~K}\left(400^{\circ} \mathrm{C}\right)$} & 0.5 & $530 \cdot \varepsilon^{0.32}$ & $\begin{array}{l}485 \mathrm{MPa} \\
\left(425 \cdot \varepsilon^{0.08} \text { above } 4 \mathrm{pct}\right)\end{array}$ \\
\hline & 2.1 & $475 \cdot \varepsilon^{0.32}$ & $460 \cdot \varepsilon^{0.08}$ \\
\hline & 3.3 & $530 \cdot \varepsilon^{0.32}$ & $493 \cdot \varepsilon^{0.08}$ \\
\hline \multirow[t]{3}{*}{$\mathrm{C}-\mathrm{Nb}-\mathrm{V}$ annealing $823 \mathrm{~K}\left(550^{\circ} \mathrm{C}\right)$} & 0.6 & $560 \cdot \varepsilon^{0.39}$ & $490 \mathrm{MPa}$ \\
\hline & 1.9 & $500 \cdot \varepsilon^{0.39}$ & $\begin{array}{l}\left(445 \cdot \varepsilon^{0.09} \text { above } 4 \text { pct }\right) \\
465 \cdot \varepsilon^{0.09}\end{array}$ \\
\hline & 4.1 & $520 \cdot \varepsilon^{0.39}$ & $487 \cdot \varepsilon^{0.09}$ \\
\hline
\end{tabular}

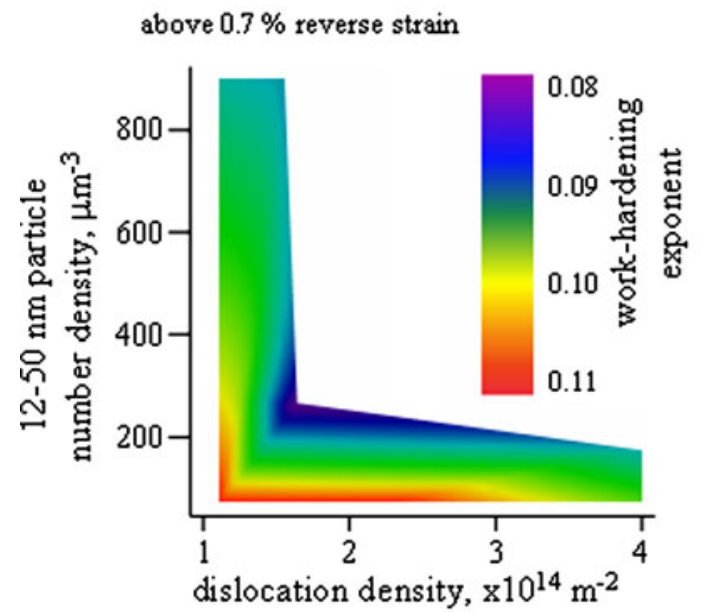

(a)

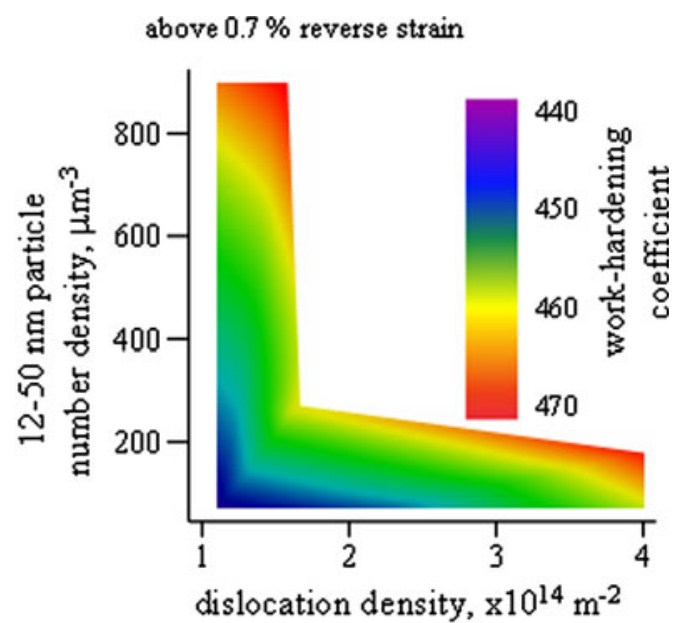

(b)

Fig. 5- (a) Work-hardening exponent and (b) work-hardening coefficient dependence on the dislocation density and $(\mathrm{Cu}+\mathrm{Ti}, \mathrm{Nb}, \mathrm{V})$-rich particle number density for the above 0.7 pct reverse strain (tension) after 2.0 pct forward prestrain (compression).

data $^{[9]}$ of the dislocation density dependence on strain for reverse deformation:

$$
\Delta \rho=\varepsilon \times 0.12 \times 10^{14} \mathrm{~m}^{-2}
$$

where $\Delta \rho$ is the dislocation density increase and $\varepsilon$ is reverse strain in percent.

\section{Killing}

Strains for the entire cross section of the pipe wall (surface layers and midthickness) were calculated using equations for compression. Particle number density for the surface layers was taken as for the plate subsurface and for the midthickness as plate midthickness (Table III). Dislocation density was taken as that after O-ing in the surface layers and as that for the initial plate midthickness for the pipe wall midthickness. The yield stress was calculated using equations for reverse work hardening (Figure 5) at the inside surface layer and using equations for forward work hardening (Figure 3) at the outside surface layer and at the midthickness. Due to the small absolute values of deformation, the dislocation density change during killing was neglected. 
Table III. Stress-Strain Curve Determination and the Yield Stress Calculation During Forming of a $914 \times 25 \mathrm{~mm}$ Pipe from the C-Nb-V Steel

\begin{tabular}{|c|c|c|c|c|c|c|c|c|}
\hline \multirow{2}{*}{\multicolumn{2}{|c|}{ Forming Stage }} & \multicolumn{3}{|c|}{ Initial Conditions } & \multicolumn{2}{|c|}{ Forming Parameters } & \multicolumn{2}{|c|}{ Yield Stress, MPa } \\
\hline & & $\begin{array}{c}\text { Prestrain } \\
\text { (Forward), } \\
\text { Pct }\end{array}$ & $\begin{array}{c}\text { Particle } \\
\text { Number } \\
\text { Density, } \mu \mathrm{m}^{-3}\end{array}$ & $\begin{array}{l}\text { Dislocation } \\
\text { Density, } \\
\times 10^{14} \mathrm{~m}^{-2}\end{array}$ & $\begin{array}{c}\text { Strain } \\
\text { (Reverse), Pct }\end{array}$ & $\begin{array}{l}\text { Stress-Strain } \\
\text { Dependence }\end{array}$ & $\begin{array}{c}\text { Across } \\
\text { Pipe Wall }\end{array}$ & Average \\
\hline \multirow[t]{3}{*}{ Plate } & inside & - & - & - & - & - & 540 & 515 \\
\hline & center & - & - & - & - & - & 490 & \\
\hline & outside & - & - & - & - & - & 540 & \\
\hline \multirow[t]{3}{*}{ U-ing } & inside & 0 & 208 & 1.2 & 4.6 (forward) & $\sigma=430 \cdot \varepsilon^{0.21}$ & 592 & 541 \\
\hline & center & 0 & 180 & 4.0 & 0 & - & 490 & \\
\hline & outside & 0 & 208 & 1.2 & 4.6 (forward) & $\sigma=430 \cdot \varepsilon^{0.21}$ & 592 & \\
\hline \multirow[t]{3}{*}{ O-ing } & inside & 4.6 & 208 & 1.9 & 1.8 & $\sigma=484 \cdot \varepsilon^{0.09}$ & 510 & 500 \\
\hline & center & 0 & 180 & 4.0 & 0 & - & 490 & \\
\hline & outside & 4.6 & 208 & 1.9 & 1.7 & $\sigma=484 \cdot \varepsilon^{0.09}$ & 508 & \\
\hline \multirow[t]{3}{*}{ "Killing" } & inside & 1.8 & 208 & 1.4 & 0.3 & $\sigma=474 \cdot \varepsilon^{0.38}$ & 300 & 451 \\
\hline & center & 0 & 180 & 4.0 & 0.3 (forward) & $\Delta \sigma=15 \cdot \varepsilon^{0.9}$ & 495 & \\
\hline & outside & 1.7 & 208 & 1.4 & 0.3 (forward) & $\sigma=484 \cdot \varepsilon^{0.09}$ & 515 & \\
\hline \multirow[t]{3}{*}{ Expansion } & inside & 0.3 & 208 & 1.4 & 1.0 & $\sigma=545 \cdot \varepsilon^{0.38}$ & 476 & 477 \\
\hline & center & 0.3 & 180 & 4.0 & 1.0 & Lüders strain & 490 & \\
\hline & outside & 2.0 & 208 & 1.4 & 1.0 & $\sigma=450 \cdot \varepsilon^{0.095}$ & 450 & \\
\hline \multirow[t]{3}{*}{ Flattening } & inside & $\begin{array}{l}0.3 \text { after } \\
\text { killing }\end{array}$ & 208 & 1.4 & $\begin{array}{l}1.0 \text { (after } \\
\quad \text { expansion })+2.9\end{array}$ & $\sigma=426 \cdot \varepsilon^{0.095}$ & 485 & 486 \\
\hline & center & 1.0 & 180 & 4.0 & 0 & - & 490 & \\
\hline & outside & 1.0 & 208 & 1.4 & 2.7 & $\sigma=434 \cdot \varepsilon^{0.095}$ & 477 & \\
\hline
\end{tabular}
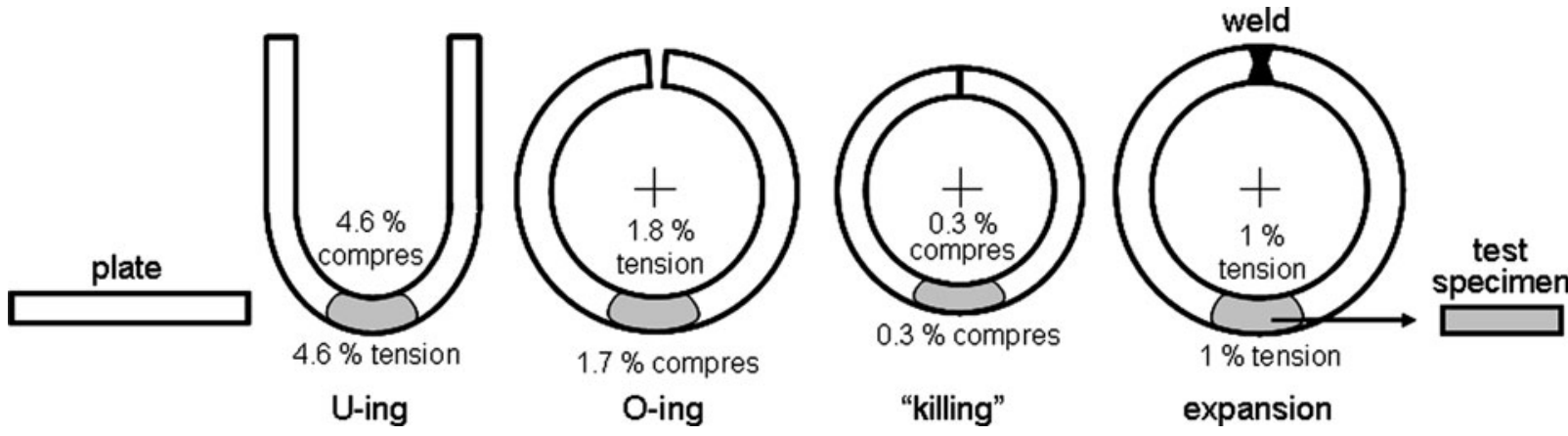

Fig. 6 - Strain development during the UOE forming of a $914 \times 25 \mathrm{~mm}$ pipe.

\section{Expansion}

Strains for the entire cross section of the pipe wall (surface layers and midthickness) were calculated using equations for tension. Particle number density values for the surface layers were taken as those for the plate subsurface and for the midthickness as plate midthickness (Table III). Dislocation density was taken as after O-ing in the surface layers and as for the plate midthickness at the midthickness. The yield stress was calculated using equations for reverse work hardening (Figure 5) in the entire pipe wall cross section. Dislocation density change during expansion was neglected.

\section{E. Flattening}

Strains in the surface layers were calculated for one deformation half-cycle, i.e., one stage of deformation from pipe cross section to a plate shape, using equations for simple bending. Particle number density was taken as that for the plate subsurface (Table III). The dislocation density was taken as after O-ing in the surface layers. The yield stress was calculated using equations for reverse work hardening (Figure 5), taking deformation during killing for prestrain in the inside surface layer and deformation during expansion for prestrain in the outside surface layer; deformation at the midthickness and associated property changes were neglected.

As seen from Table III, the calculated average yield stress in the present example decreases from plate to pipe due to the Bauschinger effect. The calculation showed that with an increase in microalloying element content, from the $\mathrm{C}-\mathrm{Nb}$ to the $\mathrm{C}-\mathrm{Nb}-\mathrm{V}$ steel, the yield stress drop from plate to pipe increases (Figure 7), which corresponds to measured data. ${ }^{[3]}$ This is due to an increase in the Bauschinger effect with an increase in dislocation density and particle number density. The calculated yield stress after flattening lies in the literature data range. ${ }^{[10,11]}$ However, the calculated yield stress is 


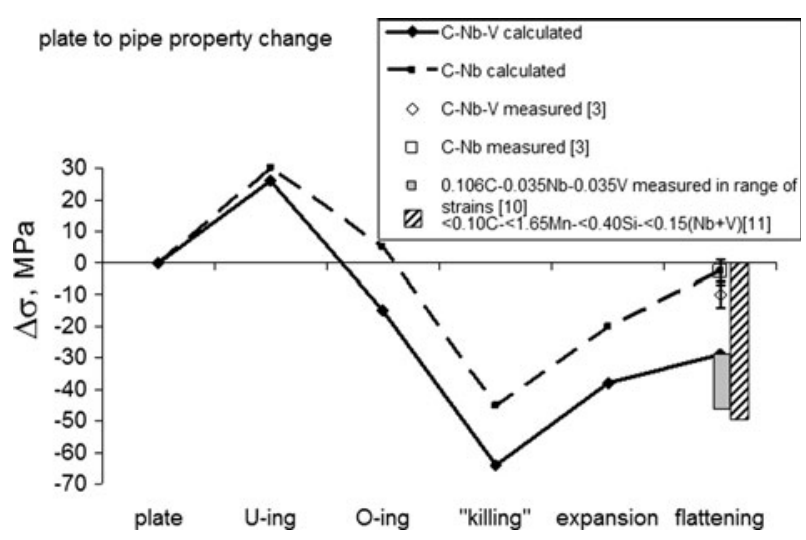

Fig. 7-Calculated yield stress change during the UOE forming process (with respect to the plate yield stress in the transverse orientation).

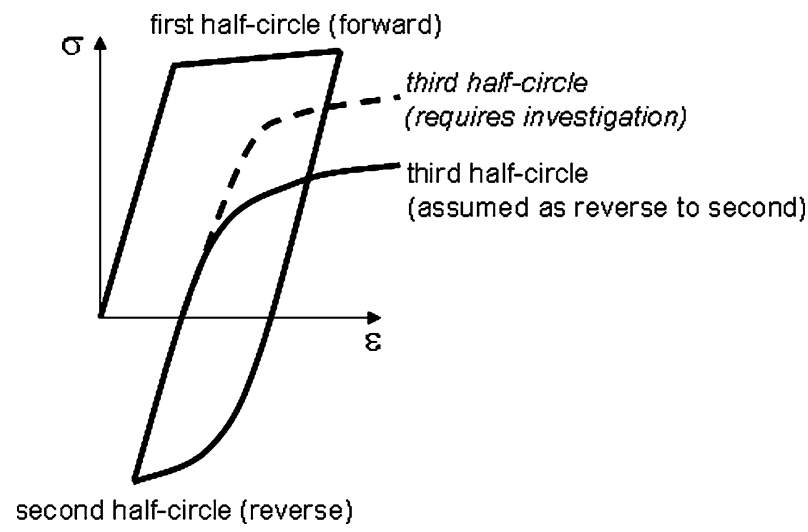

Fig. 8- Schematic presentation of the stress-strain curve assumed for the calculation.

lower, compared to the measured value for the same steel, ${ }^{[3]}$ and increases during flattening, though previously reported data show a decrease in strength from pipe to flattened specimen. ${ }^{[1,2,10]}$ This might be explained if flattening occurs not through one deformation halfcycle leading to work hardening, as was assumed during calculation, but through a series of forward-reverse deformation cycles leading to work softening. In addition, the stress-strain curve during the third deformation half-cycle (inside surface during killing and outside surface during expansion) was assumed to be dependent only on the second half-circle (O-ing) and independent of the first half-cycle (U-ing) (Figure 8). If the third halfcircle stress-strain curve goes closer to the forward stress-strain curve, the yield stress after expansion will be higher than calculated in the present example, but this requires further investigation.

\section{CONCLUSIONS}

In the present work, the strength change of two, $\mathrm{Nb}$ - and $\mathrm{Nb}-\mathrm{V}$-microalloyed, steels in the as-rolled and annealed conditions were studied during forward and reverse cold deformation. Using earlier measured microstructural parameters for the same test conditions, the parameters of work hardening (exponent and coefficient) were quantified along with their dependence on particle number density and dislocation density. The main conclusions are as follows.

1. During forward deformation, the work-hardening exponent increases and the work-hardening coefficient decreases with an increase in particle number density and dislocation density.

2. During reverse deformation, the work-hardening exponent decreases and the work-hardening coefficient increases with an increase in particle number density and dislocation density.

3. During reverse deformation, the work-hardening exponent was not observed to be dependent on the prestrain value and the work-hardening coefficient increases with an increase in prestrain after a minimum at 1 to 3 pet prestrain.

4. The relative influence of the dislocation density on the parameters of work-hardening (exponent and coefficient) during forward and reverse deformation was observed to be 3 to 4 times higher than the particle number density influence.

5. Application of the obtained dependences to yield stress prediction during the UOE forming of line pipes resulted in the calculated value of the yield stress to be within $20 \mathrm{MPa}$ accuracy of the measured value and correctly predicted a yield drop.

6. A larger plate to pipe yield stress drop was observed for the more highly alloyed steel. This can be explained by an increase in the Bauschinger effect with an increase in microalloying element content.

\section{ACKNOWLEDGMENTS}

The authors thank Corus plc for the provision of test material. Thanks are due to the Department of Metallurgy and Materials for the provision of research facilities at the University of Birmingham. One of the authors (AGK) is grateful to "The Universities, UK" for awarding a scholarship to carry out his research.

\section{REFERENCES}

1. C. Ratnapuli and E.C. Rodrigues: Met. Technol., 1982, vol. 9, pp. $440-45$.

2. T.C. Harrison, R.T. Weiner, and G.D. Fearnehough: J. Iron Steel Inst., 1972, May, pp. 334-36.

3. J.P. Ormandy: Master of Philosophy Thesis, University of Birmingham, Birmingham, United Kingdom, 2000.

4. A.G. Kostryzhev, M. Strangwood, and C.L. Davis: Metall. Mater. Trans. A, 2010, vol. 41A, pp. 1399-1408.

5. D.K. Matlock, G. Krauss, L.F. Ramos, and G.S. Huppi: in Structure and Properties of Dual Phase Steels, R.A. Kot and J.W. Morris, eds., TMS-AIME, New York, NY, 1979, pp. 62-90.

6. F. Rauch, J.J. Gracio, F. Barlat, A.B. Lopes, and J. Ferreira Duarte: Scripta Mater, 2002, vol. 46, pp. 881-86.

7. G. Vincze, E.F. Rauch, J.J. Gracio, F. Barlat, and A.B. Lopes: Acta Mater., 2005, vol. 53, pp. 1005-13. 
8. A.G. Kostryzhev: Doctor of Philosophy Thesis, University of Birmingham, Birmingham, United Kingdom, 2009, www.etheses. bham.ac.uk/436.

9. T. Ono, Y. Tomota, P. Lukas, D. Lugovy, D. Neov, N. Tsuchida, and K. Nagai: Mater. Sci. Technol., 2004, vol. 20, pp. 121-25.
10. K. Nakajima, W. Mizutani, T. Kikuma, and H. Matumoto: Trans. ISIJ, 1975, vol. 15, pp. 1-10.

11. D.G. Stalheim, K.R. Barnes, and D.B. McCutcheon: Paper presented at the Int. Symp. on Microalloyed Steels for the Oil and Gas Industry, CBMM-TMS, Araxa, Brazil, Jan. 23-25, 2006. 